\title{
Improving Students Character Using Fairy Tales
}

\author{
Martono \\ Universitas Tanjungpura, Pontianak, Indonesia \\ E-mail:martono_fkipuntan@yahoo.co.id
}

\begin{abstract}
In the 2003 National Education System Law, education is a conscious and planned effort to realize a learning atmosphere and learning process so that students actively develop their potential to have spiritual strength, self-control, personality, intelligence, noble character, and skills. it needs itself, society, nation, and country. Educational goals in Indonesia shape the noble character of students. To realize that, fairytale learning is one of them that can be used. It examines the values contained in fairy tales, so research is conducted. The form of this research is qualitative, and the research method is a description. Data collection techniques study documents. Fairy tales that are used as data sources accessed on the internet and storybooks. The sociology of literature approach is used to analyze data. Fairy tale oral literature has values that can be used to instill positive character in students. The values that are reflected in the fairy tales studied are the values of caring for the environment, thinking wisely before acting, the greedy nature of bringing disaster. The activity of appreciating fairy tales is closely related to training to sharpen feelings, reasoning, and imagination, as well as sensitivity to society, culture and the environment. Students are expected to be able to enjoy, appreciate, understand, and utilize literary works to develop their personality, broaden their horizons, and improve their knowledge and language skills. With a lot of reading literary works will help students become cultured humans who are responsive to noble values in social life. Students who are cultured are expected to be great human beings but still simple, free but self-controlled, strong but full of tenderness.
\end{abstract}

Keywords: Character; Students; Fairy Tales

\section{INTRODUCTION}

A person's character is highly developed based on the potential brought from birth or known as a basic character that is biological. Character can be formed through education because education is the most effective tool for awakening individuals in their identity as human beings. This is in accordance with the purpose of education is to character formation manifested in the essential unity of the subject with the behavior and attitude of life that he has.

It is expected that education will result in human qualities that have the subtlety of mind and soul, have the brilliance of mind, physical fitness, and have an awareness of self-creation. Exactly if we look at the basis of the law of education in Indonesia, namely: In Law Number 20 of 2003 concerning the National Education System, a commitment to character education is stated in Article 3 which states that national education functions to develop the ability and shape the dignified character and national civilization In order to educate the life of the nation, the aim is to develop the potential of students to become faithful and fearful people of God Almighty, noble, healthy, knowledgeable, capable, creative, independent, and become demographic citizens and responsible.

Many ways can be done to shape the character of students. One of them is through the field of study of Indonesian language and literature. Learning Indonesian language and literature in schools can be used to shape the character of students as our beloved nation's next generation. It is expected that students have the ability to use Indonesian language to improve intellectual abilities (creative thinking and discipline, use common sense, apply useful knowledge, understand and pursue abstract concepts, and solve problems), emotional and social maturity. Material that can be chosen is, for example, a fairy tale. Why is it fairy tale? What's wrong with a fairy tale. What is the tale about? On this occasion, the author will share the experience of forming positive character students in schools using fairy tales.

\section{RESEARCH METHOD}

The type of research conducted is the study of literature by looking for several references related to the problems found. The data used in this study are primary data obtained from the internet, books, and journals that are 
relevant to research. These data are analyzed using descriptive analysis method by describing the facts found and analyzing and providing explanations related to the problems found.

\section{DISCUSSION}

\section{Learning Indonesian Language and Literature}

Indonesian Language and Literature Learning, in addition to improving language skills, also to improve thinking and reasoning skills, as well as the ability to expand horizons. This learning is directed to sharpen students' feelings of sensitivity. Students are expected not only to be able to understand the information conveyed in a straightforward or direct manner, but also those which are conveyed in a veiled or indirect manner.

Literary learning is intended to improve students' ability to appreciate literary works. Literary appreciation activities are closely related to training to sharpen feelings, reasoning, and imagination, as well as sensitivity to society, culture, and the environment. Students are expected to be able to enjoy, appreciate, understand, and utilize literary works to develop their personality, broaden their horizons, and improve their knowledge and language skills.

On this basis, it is also said that we need to carry out literary education that is humanistic, oriented to the truth, and eager to love life, nature, and God. Therefore, literary education requires learning material that is in accordance with the above objectives. Literature compilation and extraction activities that contain the nation's cultural values need to be done (Decision of the Indonesian Language Congress V, 1988: 9).

It is expected that students are able to enjoy, appreciate, understand, and utilize literary works to develop their personalities, broaden their horizons, and improve their knowledge and language skills. Reading literary works will help students become cultured people who are responsive to noble values in community life. Students who are cultured are expected to be great human beings but still simple, free but self-controlled, strong but full of tenderness.

Literary learning is part of the subjects given at school. Literary learning is intended to improve students' ability to enjoy, appreciate and understand literary works. Furthermore, the aim is that students can write literary works, such as poetry, prose, and drama scripts.

\section{Character building}

Education is a conscious and systematic effort in developing the potential of students. Education is also an effort of the community and the nation in preparing its young generation for a better life for the people and nation in the future. Sustainability is marked by cultural inheritance and character that has been owned by the people and nation. Therefore, education is a process of cultural inheritance and national character for the younger generation and also the process of developing the nation's culture and character to improve the quality of life of the people and nation in the future. It is very closely related to education and character, and culture.
There are two kinds of paradigms in character education. First, looking at character education within the scope of a narrower moral understanding. Second, looking at character education from the point of view of understanding broader moral issues, especially seeing the whole event in the world of education itself (Martono, 2010: 115).

According to Singh (2000: 175), character is a character or habit. The character in the view of psychology is a system of beliefs and habits that lead to the actions of an individual. Wyne (in Sundusiah, 2009) argues that the character comes from Greek which means "to mark" (marking) and focuses on how to apply the value of goodness in the form of actions or behavior. Based on some of these meanings, the character is personality of a person formed from the results of internalization of various virtues that are believed and used as the basis for the perspective, attitude of life, thinking, and acting.

Character education is education to shape a person's personality through character education whose results are seen in one's real actions, namely good behavior, honesty, responsibility, respect for the rights of others, hard work, and so on (Lickona, 1991). The basic nature of character education is that what has become human potential must be developed. This also means, in humans, there are potential seeds of truth and goodness that must be encouraged through education for the actual.

According to Koesoema (2007), character education is a social aid so that individuals can live their freedom in living together with others in the world. Character education aims to shape each person into a person who is of the highest importance. In the end, each individual becomes more aware and appreciates his individuality, is able to reach the freedom he has but remains morally responsible by paying attention to the existence of others. Character education not only deals with the cultivation of values for students but is a joint effort to create an educational environment where individuals can live moral freedom.

Three important components of character education, namely knowledge about morals or moral knowledge, feelings about moral or moral feeling, and moral or moral actions (Lickona, 1992). This is necessary so that students are able to understand, feel, and do virtue values.

Characters as a 'moral excellence' or morals are built on various virtues which in turn only have meaning when based on values that apply in culture (nation). The character of the Indonesian nation is the character possessed by the citizens of the Indonesian nation based on actions considered as a virtue based on the values prevailing in the Indonesian society and nation. Therefore, National Character Education is directed at developing the values that underlie a virtue so that it becomes a self-personality of citizens.

Character education can be said to be a process for improving human personality. This is a human effort to make himself a noble human being. Basically in humans flowing habits or good behavior. The process of internalizing the main values or positive values that exist in humans. 
Character education instills good habits. Good habits are carried out and practiced continuously. In addition, the aspect of feeling is needed in character education. Basically, moral deeds are the result of two other character components. There is a motivation that encourages someone to do good. There are three other aspects of a character that must be seen, namely: one's competence, desires, and habits.

Character education will broaden students' horizons about moral and ethical values that make students more able to take decisions that are morally accountable. In this context, character education applied in our educational institutions can be one of the means of civilization and humanization. This can be done through curriculum planning and learning strategies by teachers so that a good learning environment can be felt by students (De Souza, et al, 2007). The impact of this is to create an environment that respects human life, and produces individuals who have balanced intellectual and moral abilities so that society will become more human.

In the context of schooling, character education leads students with their potential to be faithful and pious, noble, disciplined and disciplined in accordance with existing regulations, polite, honest and diligent in studying, respecting fellow human beings, and caring for their environment.

\section{The nature of fairy tales}

A fairy tale is a collective short story of oral literature. A fairy tale is folklore that is considered not really happening. Tales are told mainly for entertainment, although many also describe the truth, contain lessons (moral), or even innuendo (Danandjaya, 1991: 83). Dongen is a story that is considered never happened. Dongen is basically told for entertainment for children. Tales told are not related to time and place. According to Antti Aerne and Thomson (in Danandjaya, 1991: 83) fairy tales can be classified into four major categories, namely: 1) fable, 2) ordinary folktales, 3) jokes and anecdotes (jokes and anecdote), 4) formula tales.

1) Fable

The fairy tales of animals are fairy tales that are inhabited by pets and wild animals, such as mammals, birds, creeping things, fish, and insects. These animals in this type of story can speak and understand like humans. Examples of mouse deer and crocodiles.

2) Ordinary fairy tales

Ordinary fairy tales are a kind of fairy tale that is centered on humans and usually about someone's sad story. Examples: Bujang Nadi and Dara Nandung, Bawang Merah and Bawang Putih.

3) Jokes and anecdotes (joke and anecdote)

Jokes and anecdotes are fairy tales that can cause feelings of ridicule, which gives laughter to those who listen and tell them. Example: Si Kabayan.

4) Formula tales

The fairy tales are fairy tales that have a repeated structure or repetition. This tale has several sub-forms, namely: (1) cumulative tales. This fairy tale is formed by adding more detailed information to each core repetition of the story, (2) a fable to play with people (catch tales) is a fictional story that is told specifically to deceive people because it will cause their listeners to express unwise opinions, (3) fairy tales those who have no end (andlles tales) are fairy tales that if passed will not reach the final limit.

\section{Fairytale function}

According to Hadish, (1979: 1) Oral literature has an important function in life because it can reflect people's lives and instill a sense of love for their own culture. According to Bascom (in Danandjaya, 1991: 19), the function of oral literature is (a) as a projection system (projective system), namely as a means of reflecting the dreams of a collective; (b) as a means of ratifying cultural institutions and institutions; (c) as a children's educational tool (pedagogical device); and (d) as a means of coercion and supervision so that community norms will always be obeyed by their collective members.

\section{A Positive Value of Fairy Tales as a Character Formation Media}

Examples of fairy tales 1. Value of Caring for the Environment

\section{Fires in the Forest}

There was a big fire in the forest. All the animals fled together to the side of the lake that was not burned, and they stared at the blazing fire. A small bird sees what happens, then takes a drop of water with its small beak and drops it on the coals. The bird returned and took another drop of water to drop on the coals. The bird continues to fly back and forth diligently.

All the other animals just stared at the bird and said: "He thought he could do it with one drop?" Finally, they asked the bird. "Tell us, little bird, do you think you can put out that fire with only drops of water?"

The little bird answered: "I have to do what I can do." When he finished talking, the Angel passed by and saw the small bird and dropped heavy rain on the burning forest. Finally, a blazing fire can be extinguished. (Henny trailes, in Respati, 2004: 262).

There is a value that can be taken from the tale. Concern about events that occur in our environment. Do everything possible and as hard as you can when doing help. Even though people around us are not willing to help. Check out the quote below "I have to do what I can do." What is done should not endanger yourself. Look for strategies that don't harm yourself when helping others or doing something. The values above are very valuable for students. We must instill these positive values so they can apply them to the right events. Please help to do the good that is expected to be applied by students, not help to do evil or cheating.

Examples of fairy tales 2. Thinking Wisely 


\section{The Two Goats}

Two goats walked bravely from the opposite direction on a steep mountain, when they coincidentally each arrived at the edge of a cliff below which flowed very heavy river water. A fallen tree has been used as a bridge to cross the cliff. The tree used as the bridge is so small that it cannot be passed simultaneously by two squirrels, let alone by two goats. The very small bridge will make even the bravest of people become frightened. But the two goats did not feel scared. Their pride and pride do not want to give in and give way to other goats.

When one goat put his foot on the bridge, the other goat refused to budge and also put his foot on the bridge. Finally, the two met in the middle of the bridge. Both of them still refused to budge and instead pushed each other with their horns, so the two goats finally fell into the ravine and were swept away by the very heavy flow of water below.

http://www.ceritakecil.com/cerita-dan-dongeng/Dua-EkorKambing-44

There is a value that can be taken from the tale. If we don't want to budge, stubborn or arrogant will bring disaster as evidenced by the quote "The two still refused to budge and instead pushed each other with their horns, so the two goats finally fell into the ravine and were swept away by the very heavy flow of water below. "People who have stubbornness and want to win themselves always think that they are the right or the most powerful. People who have this nature will feel great when dealing with people who are patient or give in. But it will get the stone when dealing with people who have the same nature, namely stubbornness. If people are both stubborn, they rely on emotions and muscles, not the brain and common sense. Stubborn people are very unpopular. Better to relent than to experience bad luck because of stubbornness. It's better to relent to win. People who are equally stubborn will be able to harm each of them.

\section{Examples of fairy tales 3: Greedy Traits Bringing Disasters}

\section{The Dogs and It Shadow}

A dog that gets a bone from someone runs back to his house as quickly as possible with pleasure. When he passed a very small bridge, he looked down and saw his reflection reflected from the water under the bridge. This greedy dog thinks he sees another dog carrying a bone bigger than his.

If only he stopped to think, he would know that it was only his shadow. But the dog did not think anything and instead dropped the bone he was carrying and immediately jumped into the river. The greedy dog finally struggled to swim towards the river bank. When he arrived safely by the river, he could only stand pensive and sad because the bone he was carrying was lost, he then regretted what happened and realized how stupid he was.

http://www.ceritakecil.com/cerita-dan-dongeng/Anjing-danBayangannya-60

There are values that can be taken from the tales of The Dogs and Shadows. The greedy of a person will harm him. Consider the following quote "The greedy dog finally struggled to swim towards the river bank. When he survived on the edge of the river, he could only stand pensive and sad because the bone he was carrying was lost. "Greedy people will always feel deprived. In case he has got something that can meet his needs. People who have greedy properties will harm themselves and others because friends, neighbors will not want to be friends with people who have greedy or greedy qualities. Something that has been obtained can be lost due to greed or greed. In social life, we must want to help fellow human beings. Eliminate greed or greed in us.

\section{CONCLUSION}

Education is a conscious and systematic effort to develop the potential of students. Education is also a community and nation's effort in preparing its young generation for a better life for the people and nation in the future. Education is the most effective tool for awakening individuals in identity as human beings who are aware that good character is very important in community life. Therefore, character education is very important to be instilled in students.

Character education can be said to be a process for improving human personality. This is a human effort to make himself a noble human being. The basic nature of character education is that what is to be a positive human potential must be developed. This also means, in humans, there are potential seeds of truth and goodness that must be encouraged through education for the actual.

Indonesian Language and Literature Learning, in addition to improving language skills, also to improve thinking and reasoning skills, as well as the ability to expand horizons. Especially literary learning is intended to improve students' ability to appreciate literary works. Fairy tale oral literature has values that can be used to instill positive character in students. The values that are reflected in the fairy tales studied are the values of caring for the environment, thinking wisely before acting, the greedy nature of bringing disaster. The activity of appreciating fairy tales is closely related to training to sharpen feelings, reasoning, and imagination, as well as sensitivity to society, culture and the environment. Students are expected to be able to enjoy, appreciate, understand, and utilize literary works to develop their personality, broaden their horizons, and improve their knowledge and language skills. Generally literary works and fairy tales, in particular, there are values that can be used to foster the positive nature of students. Good tales are used to instill the positive nature of students in elementary school. 


\section{REFERENCES}

Aesop. (2017). http://www.ceritakecil.com/cerita-dandongeng/Anjing-dan-Bayangannya-60. Diakses 1 Mei 2017.

Aesop. (2017). http://www.ceritakecil.com/cerita-dandongeng/Semut-dan-Belalang-43. Diakses 1 Mei 2017.

Badan Standar Nasional Pendidikan. (2006). Standar Isi. Jakarta.

Badan Standar Nasional Pendidikan. (2006). Panduan Penyusunan Kurikulum Tingkat Satuan Pendidikan Jenjang Pendidikan Dasar dan Menengah. Jakarta.

Badan Standar Nasional Pendidikan. (2006). Contoh/Model Silabus Mata Pelajaran Bahasa Indonesia. Jakarta.

Berry, John W; Ype H. Poortinga; Mashall H. Segall; Pierre R. Dasen. (1999). Psikologi Lintas-Budaya: Riset dan Aplikasi. Terjemahan Edi Suhardono. Jakarta: PT Gramedia.

Danandjaya, James. (1991). Folklor Indonesia. Ilmu gosip, dongeng, dan lain-lain. Jakarta: Temprint.

Daradjat, Zakiah. (2001). Pembinaan Akhlak di Tingkat SMTA dan Perguruan Tinggi. Dalam Rama Furqona (ed). Pendidikan Agama dan Akhlak Bagi Anak \& Remaja. Ciputat: PT. Logos Wacana Ilmu.

Darma, Budi. (1984). 'Moral dalam Sastra' dalam Andy Zoeltom (editor). Budaya Sastra. Jakarta: Rajawali.

De Souza, M., Durka, G., Engebretson, K., Jackson, R., \& McGrady, A. (Eds.). (2007). International handbook of the religious, moral and spiritual dimensions in education (Vol. 1). Springer Science $\&$ Business Media.

Koesoema, Doni. (2007). Pendidikan Karakter Strategi Mendidik Anak di Zaman Global. Jakarta: PT. Grasindo.

Lickona. T. (1992). Educating for Character, How Our School Can Teach Respect and Responsibility. New York: Bantam Books.

Martono, (2010). Pembentukan Karakter Generasi Muda Melalui Pembelajaran Bahasa dan Sastra Indonesia. Dalam Novi Anoegrajekti, Sudartomo Macaryus, dan Endry Boeriswati (Eds.) Idiosinkrasi. Jakarta: UNJ dan Kepel Press.

Singh, Agwan. (2000). Encyclopedia of The Holy Quran. New Delhi: Balaji Offset.

Sumardjo, Jakob, \& Saini K.M. (1991). Apresiasi Kesusastraan. Jakarta: Gramedia Pustaka Utama.

Tillman. Diane. (2001). Pendidikan Nilai untuk Anak Usia 8-14 Tahun. Terjemahan Adi Respati, Aity Sikidjo, Daniel Amor, Josephine Juwana, Ramadhiana Taharani. 2014. Jakarta: Grasindo.

Undang-Undang Republik Indonesia Nomor 20 tahun 2003 Tentang Sistem Pendidikan Nasional. Jakarta.

Wellek, R. dan Warren, A. (1977). Teori Kesusastraan. Terjemahan Melani Budiman. Jakarta: PT Gramedia.

Widdowson, H.G. (1979). Stylistic and The Teaching of Literature. London: Longman. 